\title{
A SHORT HISTORY OF APPROACHES TO DISABILITY IN THE NETHERLANDS
}

\author{
Luc Brants, Paul van Trigt and Alice Schippers
}

\section{Introduction}

On the 19th of September 2011, one day before Budget Day, many people with disabilities demonstrated in The Hague against the budget cuts in social and health services that were planned by the Dutch government. Among the protesters was a group of disability activists operating under the name Terug naar de bossen (Back to the woods). The name of this group refers to the situation before the 1990s, when many people with disabilities were housed in institutions in the countryside. Since then, many people with disabilities have left these institutions and have taken their place in society. This recent activism has emerged because "this state of equality is threatened by measures of the government" (www.terugnaardebossen.nl, 2012). Terug naar de bossen places itself explicitly in the tradition of disability activism as was developed during the 1970s (www.terugnaardebossen, 2012). But, as was the case 40 years ago, Dutch disability activism is not very strong and does not receive much attention in the media. Why this is the case is one of the issues that we want to explore in this chapter.

Although disability (history) has not received much attention in Dutch historiography, with the exception of mental illness and intellectual disability, it is possible to give a historical sketch. We start with presenting the so-called new disability history as the perspective from which we, as far as possible based on the existing literature, write a modern Dutch disability history. The starting point is the notion that disability is at least partially a sociocultural construction. Thereafter, we outline the most important political developments of Dutch history (1800-2012) to set the general context. Then we describe the main developments in the way people with disabilities have been approached in society, following the themes of education, work, housing, and care. We trace the continuing and changing perspectives on various disabilities throughout this time period. We end the chapter with some concluding remarks.

\section{New disability history}

The history of people with disabilities in the Netherlands that is available to date is dominated by three different perspectives: the history of education, institutional history, and medical history (Van Trigt, 2013). ${ }^{11}$ In recent years, such perspectives in other countries have been enriched by other perspectives, especially the American 
tradition of new disability history, a viewpoint of disability history that has not been used frequently up to now in the Netherlands. Fundamental to this view is that, as in disability studies in general, in disability history social constructivism has replaced the medical view on disability. A landmark book that described this shift was The New Disability History: American Perspectives by Longmore and Umansky (2001). These and other authors espousing new disability history have postulated that disability should become a standard analytical category in the toolbox of the historian, alongside such concepts as gender, race, and class. We need another "other," argued Catherine J. Kudlick (Kudlick, 2003, p. 763) in a well-known review article. The emphasis historians like Longmore and Kudlick place on disability as a concept marked a shift in the field: in the 1970s and 1980s disability history in the US was a history of a discriminated minority, but from the 1990s onwards historians became increasingly concerned with the question of how disability functions as a socio-historical construction. People with disabilities were no longer reduced to their impairment (as in the medical model), but according to the so-called social model of disability - and other concepts - they were considered within the complex and interwoven set of relationships between the biological and social worlds (Kudlick, 2003).

The perspective of new disability is fruitful for two reasons. First, this perspective challenges us to look beyond the dichotomy healthy-ill to the way in which society constructs normality and deviation. The second reason lies in the plea of new disability historians for a "history from below," where people with disabilities and their sources are made central. Because of the current state of historic research, it is not possible to write this article radically from a new disability perspective, but, inspired by this perspective, we take as our guide as much as possible the inclusion and exclusion of people with disabilities in Dutch society.

\section{The Dutch nation, pillarization and the welfare state}

Disability is mainly perceived as a modern phenomenon, which began to be described as a category onto itself at the end of the eighteenth century. In the decades around 1800 , much of the modern Western European states were formed. The Dutch kingdom was established in 1813 after a period of revolution and French occupation. Under the absolute monarch William I, the provinces of the premodern Dutch republic were forged into a Dutch unitary nation-state. Relations between the different levels of government (national, provincial, and municipal) were reorganised, and measures were taken to give the state, rather than the dominant churches, a role in poor relief. Meanwhile, the (liberal) bourgeois elites took various initiatives to help and to educate certain groups of those who were both poor and disabled (De Haan, 2003).

In 1848, a relatively liberal constitution was introduced in which the power of the king was restricted in favour of the parliament. In this new political order, citizens were given the right of free association. The Protestant and Catholic elites used this right as an opportunity to organize themselves politically and to mobilize "their" people. In later decades, socialism emerged in the Netherlands and grew into a new, non-religious community. All these developments led towards a process of ideological pluralism often described as pillarization (Stuurman, 1983). The Dutch historian Peter van Rooden has argued that the social imaginary of the pillarized society was dominant between 1880 and 1960. In the pillarized society, religion and ideology were 
used as a method of distinguishing between people and of creating social groups. Van Rooden described the emergence of what he called social worlds, especially built up by Catholics and Orthodox Protestants, as "starting with separate educational systems, but spilling over, eventually, into almost all aspects of social life" (Van Rooden, 2007, p. 147). Regarding the care for people with disabilities, pillarization meant that the state gave a general policy framework, but the actual execution of these policies was left to private organizations of the different "pillars."

The Dutch welfare state was built up during what is called the "long sixties" (1958-1973). Compared with other western countries, this occurred later, but it was very extensive and developed in a short period of time. Within 15 years, a fully statefinanced social security system was realized, which no longer was seen as a favour but rather as a right. In the execution of these rights, the "pillarized" organizations remained important players, at least until the 1970s. The new social security system was introduced, without undue political turmoil, in a period of unprecedented economic growth and subsequent wealth (Harinck, 2009; Van Kersbergen, 2009). But soon after its realization, it began to be contested. The economic recession of the late 1970s and the 1980s was diagnosed in terms of economic politics: maintaining the welfare state would be too large a burden for the working population and the business community. This debate is still going on, as illustrated by the demonstration described in the first sentence of this chapter.

\section{"Uplift" of the blind and deaf}

We situate the beginning of Dutch disability education history in the last decade of the eighteenth century, when Daniël Guyot founded his school for the deaf-mute in Groningen (Josephus Jitta et al., 1938, p. 141). Together with the first school for the blind, which began operations in 1808 in Amsterdam (Joshephus Jitta et al., 1938, p. 171), this initiative can be seen as the first specialized form of education for people with a well-defined disability. Both schools were initiated by so-called enlightened Protestant elites, who were fascinated by the lack of sensory abilities and wanted to "uplift the people" by developing specific education for specific groups (Rietveld-van Wingerden \& Tijsseling, 2010; Vos, 2008). When religion became a dividing factor in Dutch society, new initiatives for people with sensory disabilities were taken by the different religious groups. Catholics started their own institute for the deaf in 1840 and for the blind in 1859, followed by orthodox Protestant institutes for the deaf in 1891 and for the blind in 1919 (Josephus Jitta et al., 1938, pp. 141, 171).

These institutes all started as schools that taught their students how to deal with their disabilities. The goal was to make their students "useful" citizens. For reasons of distance between homes and school, the students were also housed in a boarding school or in foster families. In this way, education and housing became indiscernibly connected. But this connection, and thus the whole policy of "uplifting" people with disabilities in this way, also had segregating effects because it set these students apart in society. When students had finished school and had to return to their own social environments, it was difficult in many cases for them to find work. To resolve this, these early institutes established separate homes for adults, in some cases with workshops for sheltered employment attached to them. Although some people with 


\section{L.BRANTS, P. VAN TRIGT, AND A.SCHIPPERS}

sensory disabilities remained outside the institutes, segregation was the dominant way Dutch society approached people with sensory disabilities.

The deaf and the blind were virtually the only groups with a bodily impairment who were subject to public interest in the nineteenth century. Other groups with bodily impairments were neglected. It was only at the very end of the nineteenth century when, under pressure from industrialization that made productivity of citizens especially important, a facility for the care of physically disabled children was erected. It opened a home and school in 1900 (Dietz \& Ketelaars, 1990).

This lack of interest can be explained as follows. First, people with bodily disabilities did not form a well-defined group with clear-cut measures that could be taken. They were primarily seen as "ill" and treated within the regular healthcare system. Second, medicine was preoccupied with other problems that were seen as more urgent. During the whole nineteenth century, the combat of infectious diseases took much energy (Houwaart, 1991). Furthermore, towards the end of the century, worries around the (supposed) increase in numbers of "idiots" and the "feebleminded," as they were increasingly called, grew. This concern became the subject of the Mental Hygienic movement, that was concerned with improving overall societal mental health (Brants, 2004, p. 21).

\section{Mental disorders as a problem}

People with a mental disorder, whether categorized as psychiatric or intellectual, were the subject of many discussions. These grew in number and intensity towards the 1910s. As in many other European countries, the Dutch approach to care for people with mental disorders had its roots in the late Middle Ages, when towns and cities began offering special houses for these groups. These so-called dolhuizen (madhouses) were mostly intended for the "raging mad" - those who caused problems or danger for themselves or other people (Mans, 1998). In the nineteenth century, some statutory regulations for the care of the "insane" were made by the national state. The risk for society was one of the driving forces behind this: the "insane laws" of 1841 and 1884 were first and foremost instruments of public order. But safety for the public was combined with the idea that the insane were ill, could be treated, and, at least in theory, could be cured in the medical institutions that emerged beginning in the middle of the nineteenth century (Van der Grinten, 1987, p. 38). The key to these institutions was given to physicians: they could write a "declaration of insanity," which led to admittance in a medical institution. This meant that they could mark the difference between what was considered to be mentally normal and abnormal.

Recent research shows that it was primarily people who caused too much nuisance or danger for their surroundings who were sent to these institutions (Vijselaar, 2010). But the boundaries between society and institutions were not as rigid as was often assumed in the Foucaultian narrative of the "great confinement." Like those in other countries (Brown \& Radford, 2015), residents of institutions often returned to society and to the care of their families when their behaviour showed amelioration (Vijselaar, 2010).

The inhabitants of these institutions formed a very diverse group. Besides patients with psychiatric diseases like schizophrenia, depression, and manic-depression (now called bipolar disorder), people who were known as idiots, and people with dementia 
and seizure disorders were also admitted (Vijselaar, 2010). From the middle of the nineteenth century onwards, people referred to as idiots were increasingly treated separately, often living in separate quarters. This was the beginning of the differentiation of mental disorder and mental disability in the Netherlands, which had already become standard practice in the surrounding countries.

In education, there was already a specific treatment for idiots, thanks to vicar Cornelis Elisa van Koetsveld, who opened his School for Idiots in The Hague in 1855. It was a boarding school with special education for children we now think of as having intellectual disabilities, and was based on the framework provided by the schools for the deaf and blind. The idea that mentally disabled children could be taught originates from this institute. It led to a growing conviction that this education should be available to all mentally disabled children. In 1896, the first classes for children were introduced into general education, when Daniël Köhler began an experiment at his own public school in Rotterdam. This "special" education was soon moved to separate schools, which in the first decades of the twentieth century grew considerably. This growth occurred for two important reasons. First, "normal" education embraced it as a way to get rid of children who slowed down or disturbed regular education. Second, the teachers in special education showed that mentally disabled children could be successfully taught, an idea that was embraced by the government (Graas, 1996).

\section{Aspects of class}

The approach towards people with disabilities in the nineteenth and early twentieth centuries was possible because disability was highly entangled with class - people with disabilities were mainly considered as poor people. Legal measures and charitable institutes that affected disabled people's lives were often part of the way in which elites dealt with the poor, be it in the oppressive sense (via legal measures such as the Insanity Acts) or the "uplifting" sense (via charitable societies). Disabled members of the elites were helped within their own families or in private institutions and were kept out of the scope of public interest. Even some public medical institutions had class systems (e.g., the Catholic Voorburg in Vught) in which the quality of care depended on the amount of money that was paid by the patient's family (Vijselaar, 2010).

The way disability was associated with class is also illustrated by the striking absence of the disabled people's voice. Measures were taken for them, discussions were held about them, but almost never were their voices heard. The idea that people with disabilities, or even their parents, could have their own opinions did not appear to have popped up in the minds of the elites who organized care.

\section{Social Darwinism and eugenics}

The view that people with mental disabilities were a danger to society grew in the Netherlands into "common sense" only after World War I. The teachers in Dutch special education saw the risk as manageable, which could only grow into a danger when the mentally disabled were neglected (Brants, 2004, pp. 75-76). It was enough to take social measures to help them. Against this conviction stood the belief, shared mostly by professionals with a medical background, who pleaded for more restrictive measures to limit or forbid procreation. 


\section{L.BRANTS, P. VAN TRIGT, AND A.SCHIPPERS}

Eugenic measures were, in contrast to some surrounding countries (Germany, Scandinavia), never taken in the Netherlands. The most important reason for this was the pillarization system: Catholic and Protestant morality was opposed to eugenics, and their politicians effectively blocked any eugenic measure (Brants, 2004, pp. 116-117). Nevertheless, there is a dark chapter. During the Second World War the inhabitants of a Jewish psychiatric hospital were deported and murdered (Van Wijnen, 2014). Also, there are indications that the Nazis who occupied the Netherlands planned steps against people with minor mental disabilities in 1944 (Graas, 1996, pp. 77-78).

\section{Disability as functional deficit}

As in many of the surrounding countries, in the early decades of the twentieth century, labour was increasingly seen as essential for developing human potential. It was intrinsically good and, despite its internal religious and ideological differences, Dutch society in general shared this view. Part of this common view was that education should prepare people for work, and this view applied also to people with disabilities. To attain the goal of students in special education acquiring meaningful work in their communities, organizations began to operate in the 1920s for the purpose of matching special education students with work opportunities. The main activity of this so-called "After Care" was to find students a job and to support them in their first period at work. This grew into a system of social pedagogical care. Work was important to the extent that the "social usability" of children was measured by their (in)ability to work (Brants, 2004, p. 89).

Sheltered employment was set up for people with mental disabilities who under no circumstances could find a regular job. This meant that they could work and did not have to be sent to institutions, an argument that was used to convince municipalities to subsidize these workshops. Sometimes, it was even possible to place people from institutions back into their former communities. An important aspect of this movement was that it formed a counterweight against the Social Darwinism movement, that saw people with disabilities primarily as the most "unfit" in society, the least likely to make a positive contribution, and the most likely to thus be subjected to measures that would reduce their numbers in society. It showed that people with disabilities could positively contribute to society and were not simply a burden.

Sheltered employment diversified throughout the 1920s and 1930s, and was developed for more and more different disabilities (Josephus Jitta et al., 1938), although attention to people with physical disabilities alone was still not strong. In this period, the word handicap emerged in the Dutch language and was used as a general term for all people with a functional deficit in their ability to work (www.etymologie.nl, 2011). ${ }^{22}$ Establishing and maintaining workshops remained, in this period, the responsibility of municipalities and charities, which lead to a patchwork system without a central policy from the Dutch national government.

In spite of these changes, the discourse and practice of rehabilitation was considerably less dominant in the Netherlands than in other countries, where wounded war veterans sparked the development of many new services, because of the relative small military involvement of the Dutch in the two world wars (Van Trigt, 2013). 


\section{From charity to right}

Soon after World War II, things began to change in the Netherlands. In 1950, the central government obliged municipalities to maintain workshops for people with disabilities. It was the first intervention of the National government in these matters, but it was only the beginning (Moes, 1997).

With the unprecedented economic growth of the late 1950s and the 1960s, the general idea grew that care for people with disabilities was not a matter of charity, but a right guaranteed by the state. This thinking led to reforms of the welfare system in the 1960 s, in which the association of poverty with disabilities was broken by separating poor relief from the financing of the care for people with disabilities. Under the Social Employment Law of 1969, the financing of workshops for people with disabilities was lifted to the national level. The Act on Extraordinary Medical Expenses from 1968 meant that the costs of care for people with disabilities became part of a general insurance for all inhabitants of the Netherlands. The state distributed the finances mainly among already existing social and care systems. This strengthened the segregation of people with disabilities, who now often became financially dependent on an anonymous government.

\section{Normalization?}

Was the changing role of the state in the 1960s accompanied by a changing attitude towards people with disabilities? Until the 1960s, the defect perspective, reflected in the medical model, was uncontested. People with disabilities were seen as patients and had to be treated. A new paradigm emerged, the normalization principle, which meant making available to people with mentally disabilities, as much as possible, the norms, patterns, and conditions of everyday life in mainstream society (Nirje, 1969; Van Gennep, 2007; Vos, 2008). This principle was rooted in the social policies of the social-democratic government of Sweden and aimed to mainstream public services like housing facilities, education, and work.

In the Netherlands, the normalization principle was never fully embraced, mainly because disability services continued to be segregated in character. Segregated special education kept expanding, in numbers as well as in types of education. What began as education for the blind, the deaf, and the mentally disabled grew into 15 forms of special education and, in 1994, almost $5 \%$ of all children in the primary age group attended special education (Graas, 1996, p. 235). The increase in numbers can also be seen within the realm of the sheltered employment. Based on the idea that people with disabilities had the right to work, in 2006 approximately 90,000 people were involved in sheltered employment (www.canonsociaalwerk.eu, 2015).

"Dutch" normalization showed most clearly in the way facilities for people who needed extensive care and support were organized. From the 1970s onwards, there was a building boom of small-scale locations constructed in neighbourhoods and villages (Mens \& Wagenaar, 2010, pp. 90, 132, 192; Weijers, Tonkens, \& Mans, 1998, p. 319). This was normalization "in bricks," because little attention was paid to the development of social interaction with the surrounding "normal" society. Policy planners and care professionals still had the lead, not people with disabilities or their advocates. This style of normalization mostly reflected the concerns of professionals 
and their services, rather than the social context that is essential for integration (Chappel, 1997).

As a result of this paternalistic normalization, self-advocacy emerged slowly. Only the sensory disabled communities had organized themselves in the pre-war period, partly in pillarized groups. In the 1950s, parents of people with intellectual disabilities organized themselves according to the Dutch pillarized model. These associations became very powerful and even established care facilities themselves. But because it was the parents who were the organizers, the voice of people with disabilities themselves was still not heard. In the 1970s and 1980s, self-advocate associations were founded by people with mental disorders and by people with intellectual disabilities. These were no longer based on different ideologies, and the number of self-advocate associations has increased since that time.

\section{Pressure for change}

Since the 1980s, special education, sheltered employment, and decentralized living accommodations became more and more questioned. The government has tried to reduce costs of special education and sheltered employment by reducing the numbers coming into these systems. Special education was reformed by the slogan together to school again and was renamed in 2011 into fitting education, in which support of children with disabilities in regular education is now a core government policy.

Regarding sheltered employment, since the 1980s workshops have had to operate in an economically competitive manner. The demands on employees increased, and more vulnerable groups were excluded from this type of work. This led to a new type of workshop for these groups, operated mostly by care providers. However, in later reforms, initiated in 2011, the government made a full swing in policy: sheltered employment is, according to these plans, meant only for those people who under no circumstance can work in the broader economy.

The trend in government policy for living accommodation since the 1990s has been towards providing respite and short-term care (in order to postpone admission to residential care), and integrated places of living (Oosterhuis \& Gijswijt-Hofstra, 2008, p. 1232). The initial idea of community support seems to have failed here, but not because of a lack of "bricks." To the contrary, most people with disabilities who require housing now live in small-scale living accommodations in "normal" society. The problem is that the development of social interactions with the living environment has been neglected. In many cases the only interaction with people outside the homes is with family and professionals (Van Berlo et al., 2011, p. 36).

\section{Disability activism and disability studies}

One striking aspect of Dutch disability activism is the lack of strong, independent cross-disability groups, as were organized in the United Kingdom, the United States, and elsewhere. In the 1970 s there were some disability-related protests, but this did not grow into a strong Dutch grass-roots disability movement.

An explanation for this phenomenon might be found in the way the self-advocate associations have been structured since the 1970s. They are fragmented along the lines of distinct diseases and syndromes and do not have a national platform from which 
to operate. Thus, there are separations between people with mental disorders, people with intellectual disabilities, people with physical and sensory disabilities, users of care institutions, and others. Existing self-advocate associations serve much more as a discussion partner of the government and care providers than as a pressure or advocacy group. Moreover, Dutch self-advocate groups do not focus to any great extent on civil rights, but rather direct their attention to the improvement of social and care services, which are difficult to address because of the dominance of large care providers. These providers place an emphasis, as already mentioned, on physical-structural changes and have a strong orientation towards the medical point of view. This reflects in the way people with disabilities are organised - as patients and consumers of care.

Parallel to, and at least partly because of, this lack of disability self-advocacy, several attempts to establish disability studies as a field in the Netherlands failed during the 1980s and 1990s. In addition, Dutch scholars did not contribute substantially to the emerging international field of disability studies. Only seven of 1300 articles published in the journal Disability Studies between the years 1986 and 2010 are of Dutch origin (Blume \& Hiddinga, 2010). In the Netherlands, expertise and knowledge has been developed in some areas of disability, but there seems to be little awareness of scholarly and professional work among these areas.

In research, a recent initiative to establish disability studies as a coherent scientific field with its own body of knowledge seems to be fruitful. This program aims to contribute to the quality of life for people with disabilities and to promote an inclusive society by means of developing research and education that includes people with disabilities in all stages of development. Disability studies is an interdisciplinary science field, covering social, behavioural, human, and medical sciences. Technical and applied sciences, history, law, arts, and economics are also highly relevant. Synergy between these scientific fields and involvement of people with disabilities, professionals, and the public sector may bridge the gaps that currently exist among people, policy, practice, and science (Parmenter, 2011).

\section{An integrated future?}

The dominant conceptual models used in the past in the field of disabilities - medical model, social model, ecological model, and critical disability model (Bach, 2007; Hosking, 2008) - still guide Dutch disability-related research and practice to varying degrees today. However, they have increasingly been combined with cultural and historic concepts, and referred to as a contextual model. The contextual model, with its focus on integration, has slowly been adopted in recent years, as old structures fade away and people with disabilities are seen as one of the last groups to be included into society. Principles of inclusion and integration (the "next step" after inclusion) are now being implemented in educational, employment, and care systems.

Inclusion and inclusive policy and practice began in the lifestyle and care domains of disability, but were subsequently adopted in broader life domains such as work and education. Thus, inclusion and its "next-step" concept, integration, focus on all aspects of the lives of people with disabilities, but are also the focus of how systems and organizations operate. This shift is driven by an emphasis on human rights and the so-called citizenship paradigm. The emergence of this rights-based and inclusionoriented paradigm can be seen in recent Dutch policy and practice and research. In 
policy and practice, a cross-disability NGO the Coalition for Inclusion was established in 2007 and is a serious partner for policymakers in striving for ratification of the United Nations' Convention on the Rights of Persons with Disabilities (www.coalitievoorinclusie.nl, 2015). At the time of publication, legal and financial implications of ratification are being studied closely by the government, which has promised ratification by 2016. Recent partnerships among self-advocates, scientists, and policymakers indicate that lessons from the past and from abroad are being taken into account.

\section{Summary and conclusion}

Looking at the trends in the conceptual and practical approaches to disability in the Netherlands, it is apparent that Dutch developments have typically mirrored developments in surrounding countries but followed them by a delay of some years or decades. For example, at the end of the eighteenth century and the beginning of the nineteenth century, Dutch liberal bourgeois began to pay attention to their own people with (sensory) disabilities, following French examples. The emphasis at this time was on support in dealing with the disability for positive reasons, namely to "uplift" people. Later on, in the nineteenth century, society leaders began to intervene for reasons that were not positive for people with disabilities: in order to ensure public order, people who might endanger this were (temporarily) segregated. This was largely the product of the Social Darwinist and eugenic discourse that dominated the most affluent countries of the world in the late nineteenth century and first half of the twentieth century, although its influence in the Netherlands was not as strong as in some neighbouring countries. The Christian view on the care for people with disabilities, as a duty and a service, prevailed until the end of the $1960 \mathrm{~s}$, and charity remained the predominant approach in dealing with this group. Following this, the care for people with disabilities became a right, and finances were provided for disability services by the national government.

The unintended consequence of this development was the loss of ties with local communities who had previously taken care of their "own" people with disabilities. Instead, people with disabilities became financially dependent on an anonymous government. From the 1980s onwards, when on the national political level neo-liberal influence grew, economic developments started to govern much of the financing of the care for this group.

In the meantime, at the care provision level, the attitude towards people with disabilities shifted from the medical model towards a social-contextual model, in which members of the target group got a voice and were involved in the organization of their own care, although this was on a much lower level than in the surrounding countries. Care providers often merged over the past 20 years into large organizations, which still have much power. This has led to the paradoxical situation where, physically, many people with disabilities live within "normal" society, but in a social sense they are functioning in a separate world. This is a situation that is changing now very slowly.

\section{Acknowledgements}

The authors are very grateful to Prof. Dr. A.Th. G. van Gennep and Prof. Dr.J. Vijselaar, who commented on an earlier version of this chapter.

Paul van Trigt acknowledges the support of the ERC Consolidator Grant Rethinking Disability under grant agreement number 648115. 


\section{APPROACHES TO DISABILITY IN THE NETHERLANDS}

\section{Notes}

1 In two recent dissertations a more explicit link is made with the tradition of (new) disability history: Paul van Trigt, Blind in een gidsland. Over de bejegening van mensen met een visuele beperking in de Nederlandse verzorgingsmaatschappij (Hilversum: Verloren, 2013) and Corrie Tijsseling, 'School, waar?' Een onderzoek naar de betekenis van het Nederlandse dovenonderwijs voor de Nederlandse dovengemeenschap, 1790-1990 (Proefschrift Universiteit Utrecht, 2014).

2 www.etymologie.nl (retrieved December 2, 2011) shows the word was first used with the meaning of deficit in the interwar period. In the US the development of handicap was also closely linked to work; see Devlieger, P. J. (2001). "Handicap" and Education in the United States of the 1930s: Discursive formations in the New York Times, Paedagogica Historica, 37(2), 279-289.

\section{References}

Bach, M. (2007). Changing perspectives in developmental disabilities. in I. Brown \& M. Percy (Eds.), A Comprehensive Guide to Intellectual E Developmental Disabilities (pp. 35-43). Baltimore, MD: Paul H. Brookes Publishing.

Blume, S., \& Hiddinga, A. (2010). Disability studies as an academic field: Reflections on its development. Medische Antropologie, 22, 225-236.

Brants, L. (2004). Leiding moeten zij hebben. Geschiedenis van de sociaal pedagogische zorg voor mensen met een verstandelijke handicap in Nederland tussen 1900 en 1945. Antwerpen/Apeldoorn, the Netherlands: Garant.

Brown, I., \& Radford, J. P. (2015). The growth and decline of institutions for people with developmental disabilities in Ontario: 1876-2009. Journal on Developmental Disabilities, 21(2), 7-27.

Chappel, A. (1997). From normalisation to where? In L. Barton \& M. Oliver (Eds.), Disability Studies: Past Present and Future (pp. 45-62). Leeds, UK: The Disability Press.

Dietz, H., \& Ketelaars, T. (1990). Johanna Stichting 1900-1990: Negentig jaar zorg voor kinderen met een lichamelijke handicap. Arnhem, the Netherlands: Stichting Fonds Johanna Stichting.

Graas, D. (1996). Zorgenkinderen op school. Geschiedenis van het speciaal onderwijs in Nederland, 1900-1950. Leuven/Apeldoorn, the Netherlands: Garant.

Haan, I. de. (2003). Het beginsel van leven en wasdom. De constitutie van de Nederlandse politiek in de negentiende eeuw. Amsterdam, the Netherlands: Wereldbibliotheek.

Harinck, G. (2009). Religion and the Dutch Welfare State. Paper presented to the conference 'Religion, values, and the welfare state,' Münster, Germany.

Hosking, D. L. (2008). Critical disability theory. Paper presented at the 4th Biennial Disability Studies Conference at Lancaster University, Lancashire, UK., September 2-4, 2008.

Houwaart, E. (1991). De Hygienisten. Artsen, staat en volksgezondheid in Nederland 1840-1890. Groningen, the Netherlands: Historische Uitgeverij.

http:/ / www.canonsociaalwerk.eu/1920_werkvoorziening/wsw\%20in\%20beweging\%20www. pdf (Retrieved December 28, 2015).

http://www.terugnaardebossen.nl (Retrieved September 14, 2012).

Josephus Jitta, N. et al. (1938). Verslag van de Staatscommissie inzake onvolwaardige arbeidskrachten, ingesteld bij kon. Besl. van 12 April 1929. Gravenhage, the Netherlands: Algemeene Landsdrukkerij.

Kudlick, C. (2003). Disability history: Why we need another 'Other'. American Historical Review 108, 763-793.

Longmore, P., \& Umansky, L. (Eds.). (2001). The New Disability History: American Perspectives. New York, NY: New York University Press.

Mans, I. (1998). Zin der Zotheid, vijf eeuwen cultuurgeschiedenis van zotten, onnozelen en zwakzinnigen. Amsterdam, the Netherlands: Bert Bakker. 


\section{L.BRANTS, P. VAN TRIGT, AND A.SCHIPPERS}

Mens, N., \& Wagenaar, C. (2010). Architectuur voor de gezondheidszorg in Nederland. Rotterdam, the Netherlands: NAi Uitgevers.

Moes, J. (1997). Van bedelstaf tot marktwapen. Sociale werkvoorziening in Leiden na 1795. Leiden, the Netherlands: Dirk van Eek-stichting.

Nirje, B. (1969). The normalization principle. In Changing Patterns in Residential Services for the Mentally Retarded (pp. 179-196). Washington, DC: President's Committee on Mental Retardation.

Oosterhuis, H., \& Gijswijt-Hofstra, M. (2008). Verward van geest en ander ongerief: Psychiatrie en geestelijk gezondheidszorg in Nederland 1870-2005. Houten, the Netherlands: Bohn Stafleu van Loghum.

Parmenter, T. (2011). The study of intellectual disability. in H. Reinders (Ed.), Authenticity and Community (pp. 11-31). Antwerpen/Apeldoorn, the Netherlands: Garant.

Rietveld-van Wingerden, M., \& Tijsseling, C. (2010). Ontplooiing door communicatie: Geschiedenis van het onderwijs aan doven en slechthorenden in Nederland. Antwerpen/Apeldoorn, the Netherlands: Garant.

Stuurman, S. (1983) Verzuiling, kapitalisme en patriarchaat. Nijmegen, the Netherlands: SUN.

Van Berlo, W., De Haas, S., Van Oosten, N., Van Dijk, L., Brants, L., Tonnon, S., \& Storms, O. (2011). Beperkt weerbaar. Een onderzoek naar seksueel geweld bij mensen met een lichamelijke, zintuiglijke of verstandelijke beperking. Utrecht, the Netherlands: Rutgers WPF/Movisie.

Van der Grinten, T. (1987). De vorming van de ambulante geestelijke gezondheidszorg, een historisch beleidsonderzoek. Baarn, the Netherlands: Ambo.

Van Gennep, A. (2007). Waardig leven met beperkingen. Antwerpen-Apeldoorn, the Netherlands: Garant.

Van Kersbergen, K. (2009). Religion and the welfare state in the Netherlands. In K. van Kersbergen \& P. Manow (Eds.), Religion, Class Coalitions and welfare States (pp. 119-145). New York, NY: Cambridge University Press.

Van Rooden, P. (2007). Dutch concepts to express religious difference, 1572-2002. In L. Hölscher (Ed.), Baupläne der sichtbaren Kirche. Sprachliche Konzepte religiöser Vergemeinschaftung in Europa (pp. 136-150). Göttingen, Germany: Wallstein Verlag.

Van Trigt, P. (2013). Blind in een gidsland. Over de bejegening van mensen met een visuele beperking in de Nederlandse verzorgingsmaatschappij. Hilversum, the Netherlands: Verloren.

Van Wijnen, A. (2014). Het Apeldoornse Bos. De moord opjoodse verstandelijk gehandicapten. in A. Van Gennep, J. Van der Lans, M. Van der Linde, T. Post, \& P. Van Trigt (Eds.), Canon sociaal werk (pp. 38-40). Amsterdam, the Netherlands: Vereniging Canon Sociaal Werk.

Vos, J. (2008). Tastend door de tijd: Twee eeuwen onderwijs en zorg voor slechtziende en blinde mensen. Amsterdam, the Netherlands: Boom.

Vijselaar, J. (2010). Het gesticht: Enkele reis of retour? Amsterdam, the Netherlands: Boom.

Weijers, I., Tonkens, E., \& Mans, I. (1998). Verstandelijk handicap en burgerschap. Een historiografische schets. Comenius, 18, 310-324. 
AU:1 OK as changed?

Author queries

AU:2 Please provide the reference for this text citation.

AU:3 Please provide site or article names for these twoURLs (to be real aphabetized accordingly).

AU:4 Please provide all author names for reference Josephus Jitta (1938).

$\mathrm{AU}: 5 \quad \mathrm{OK}$ as corrected? 